The Impact of Work Family Conflicts on Employee Job Satisfaction: An Investigation of Employees in Private Sector Banks in Kandy District, Sri Lanka

\author{
Weerasinghe, KPNN and Batagoda, CK
}

\begin{abstract}
Area of the Study

This study discusses the effect of work family conflicts on job satisfaction of employees in private banks in the Kandy district.

\section{Problem of the Study}

There is an empirical and knowledge gap in the Sri Lankan context on the relationship between work family conflicts on job satisfaction of employees. The main objective of this research is to identify the effect of work family conflict on job satisfaction of employees in private banks in the Kandy district, Sri Lanka. The research problem of this study is that Is there an effect of work family conflict on job satisfaction of employees in private banks in Kandy district of Sri Lanka?
\end{abstract}

\title{
Method of the Study
}

The data were collected from a convenient sample of 120 employees in three private banks in the Kandy district, which refers to the collection of information from the members who were conveniently available to provide it. Data were collected using a structured questionnaire which consists of 33 questions with five point likert scales. Data were analyzed using univariate analysis, correlation and regression analysis with the SPSS(16.0 version).

\section{Findings of the Study}

According to the empirical evidence of this study, it is found that there is a negative impact of work family conflict on job satisfaction of employees in selected banks in the private sector.

\section{Conclusion of the Study}

It is concluded that there is a negative impact of work family conflict on job satisfaction of private bank employees. Thus, some programs for reducing the level of work family conflict of employees in banks could be recommended. Also a good relationship and good work environment should be maintained with employees in private banks.

Keywords: Work Family Conflict Job Satisfaction, Private Banks

\section{Introduction}

People today are becoming more and more advanced and human needs are increasing. Because of the technological advancements; humans are poised to drastic changes in life styles (Kossek \& Ozeki 1998). To satisfy these escalating needs and wants, they tend to chase after money more than ever. Thereby voluntarily or involuntarily, employees neglect family, because of the heavy work load and ambition to go for a higher position. This results in "Work Family Conflicts". "Work Family Conflict" is an emerging concept in today's context in most of the industries especially in the private banking sector. The rapid economic growth 
and development in the world has created new activities and has opened new doors for all the business organizations. Due to globalization trends, organizations find it hard to retain their competitive advantage. These trends have also affected the banking sector; thereby making banking sector more competitive.

Job satisfaction is also an important factor to consider when dealing with work family conflict. Job satisfaction can be defined as a pleasurable or positive emotional state resulting from the appraisal of one's job or job experience. A number of studies have examined the relationship between work-family conflict and job satisfaction and found that work-family conflict was negatively related to job satisfaction (Aryee 1993; Noor 2002; Aminah 1996).

The long working hours, work pressure, high demanding jobs, use of sophisticated technology made it difficult for employees to keep a balance between their job and work commitments (Nadeem, et al. 2009). This research is aimed to discuss the impact of work family conflict on job satisfaction. The study is specially referred to employees in private sector banks in Kandy District.

\section{Problem Background and Problem of the Study}

It is intended that the findings of this study will help to provide more theoretical evidence by filling the gap in the research literature concerning the impact of work family conflict on employee job satisfaction. Past studies (Netemeyer et al. 1996; Frone 2003) have explored the level of conflict between work and family obligations. This study gets an effort to measure the impact of work family conflict on job satisfaction in private banks in Kandy district.

According to literature, work family conflict is rapidly increasing. Unmarried women have greater commitment to work life than married women (Carter \& Cannon 1992). Research studies on women employees have reported that married women employees face work and family conflict, which negatively affects their job satisfaction, marital satisfaction and life satisfaction (Arora et al. 1990). This study aims to study how work family conflict affects to job satisfaction. The theoretical and empirical evidences explain the different factors of job satisfaction. It seems that there is a gap in Sri Lanka with regard to the impact of work family conflict on employee job satisfaction in private banks. Therefore the research finds out the impact of work family conflict on employee job satisfaction in private banks in Kandy district. The research problem of this study is: Is there effect of work family conflict on job satisfaction of employees in private banks in Kandy district of Sri Lanka?

\section{Research Framework}

Many researchers have found the relationship between work family conflict and employee job satisfaction. Beutell and Witting-Berman (1999) found that high levels of work family conflict are related to lower job satisfaction. Kossek and Ozeki (1998) suggested that job satisfaction is often negatively related to work family conflict. Aminah (1996) showed that negative relationship has been found between work family conflict and job satisfaction. Noor 
(2002) and Mohd Kamil (1993) also found that there is a negative relationship between work family conflict and job satisfaction. Previously Sekaran (1985) and Parasuraman, et al. (1989) presented similar studies which showed similar results. A study was conducted by Maren, Pitarelli and Cangiano (2013) to analyze work life conflict and job satisfaction among teachers which exposed a negative relationship between work life conflicts and job satisfaction. Literature showed a relationship between work family conflict and job satisfaction and according to above literature the following hypothesis is derived, Hypothesis $_{1}$ : There is a negative impact of work-family conflict on job satisfaction.

This conceptual framework mainly highlights the relationship of two variables i.e. work family conflict and employee job satisfaction. Work family conflict can be divided into two variables as, time based conflict and strain based conflict. In this conceptual model, the independent variable is work family conflict whereas the dependent variable is job satisfaction. Figure 1 depicts the conceptual framework of the study.

Figure 1: Conceptual Model

Work Family Conflict
Job Satisfaction

\section{Method}

This study was conducted in a quantitative design by collecting data through a questionnaire and the two variables were identified and tested based on the hypotheses developed. This study focuses on hypotheses testing and identifying correlation between variables. These types of studies usually explain the nature of certain relationships and explain the variance in the dependent variable. The target population of the study is employees in private banks in Sri Lanka. This research study focuses on the convenient sampling as there are many private banks in Sri Lanka and for the purpose of the study the researcher selected only 120 employees from three banks in the Kandy district. Sampling technique used for this study was the convenient sampling which refers to the collection of information from the members who are conveniently available to provide it.

\section{Measures}

A questionnaire was selected as the major source of data collection and the researcher gathered first hand data by distributing this questionnaire. This is considered to be the best and the most practical method to conduct a survey collect data from a sample of this size. The questionnaire consisted of three parts including open ended and closed ended questions. The first part contained of demographic factors. The second part contained ten close ended questions to measure the variable. Work family conflict was measured using a scale consisted of thirteen items framed by Kopelman, Greenhaus and Connolly (1983) and Stephens and Sommer (1996). Response to individual items was scaled according to a five-point Likert scale ranging from 1(strongly disagree) and 5 (strongly agree). The third part consisted of sixteen questions to measure job satisfaction. A Modified Minnesota Satisfaction Questionnaire (MSQ) was used to measure the level of satisfaction of the employees at their 
workplace. Response to individual items was scaled according to a five-point Likert scale ranging from 1 (very dissatisfied) to 5 (very satisfied).

All questions were presented as statements and employees were supposed to rank them according to the scale. Statements on surface acting and deep acting were positive statements. Data was gathered through the five point Likert scales which were positive and negative as Strongly Disagree, Disagree, Neutral, Agree and Strongly Agree for work family conflict and Strongly Dissatisfied, Dissatisfied, Neutral, Strongly Satisfied, Satisfied for job satisfaction.

\section{Reliability and Validity}

The consistency reliability was examined with Cronbach's Alpha test. The results of Cronbach's alpha test are given in Table 1, which suggests that the internal reliability of each instrument is at a satisfactory level (Kottawatta 2014).

Table 1: Reliability Statistics of Stress Measurements

\begin{tabular}{|c|l|c|c|}
\hline & Instrument & Cronbach's Alpha & No of Items \\
\hline 1 & Work Family Conflict & 0.736 & 12 \\
\hline 2 & Job Satisfaction & 0.930 & 14 \\
\hline
\end{tabular}

The construct validity of the variables of the study was ensured by the fact that the correlation and regression analysis support the hypotheses formulated linking the relationship between the independent variable and the dependent variable (Kottawatta 2014). The construct validity of the variables of the study was ensured by the fact that the correlation and regression analysis support the hypotheses formulated linking the relationship between the independent variables and the dependent variables (Kottawatta 2014).

\section{Techniques of Data Analysis}

After gathering data they were analyzed by using the computer based statistical data analysis package, SPSS (version 16.0) for validity, reliability and relationship testing. Univariate analysis and bivariate analysis were applied in data analysis.

\section{Results}

According to Table 2 total valid respondents are 100 and the mean value of work family conflict is 3.3056. It indicates that the work family conflict level of the private banks employees of the selected banks is "high". The standard deviation of the level of work family conflict is 0.597 . It is less than 1 and it indicates that the dispersion is very low and the majority is centered towards the mean. Then it indicates that the level of work family conflict of the majority of the employees is high. The mean value of job satisfaction is 3.75 . It is very close to 4 and it indicates that the level of performance is "high". The standard deviation of satisfaction is 0.65 and indicates the majority is centered towards the mean. 
Table 2: Descriptive Statistics on Job Satisfaction and Work Family Conflict

\begin{tabular}{|l|c|c|}
\hline & Job Satisfaction & Work Family Conflict \\
\hline Mean & 3.7589 & 3.3056 \\
\hline Median & 2.8000 & 3.2500 \\
\hline Mode & $2.27 \mathrm{a}$ & 3.67 \\
\hline Std. Deviation & .65898 & .59761 \\
\hline Variance & .434 & .357 \\
\hline Skewness & .670 & -.137 \\
\hline Std. Error of Skewness & .243 & .243 \\
\hline Kurtosis & .708 & 2.494 \\
\hline Minimum & 1.27 & 1.00 \\
\hline Maximum & 4.87 & 5.50 \\
\hline
\end{tabular}

In order to test the hypothesis the Pearson Correlation Technique was used. The desired significant level was 0.05 and two tailed test were used because the hypothesis is non directional which indicates the significant relationship between the work family conflict and job satisfaction. Table 3 presents the results of the correlation test.

Table 3: Correlation between Work Family Conflict and Job Satisfaction

\begin{tabular}{|l|l|r|r|}
\hline \multirow{3}{*}{ JS } & & JS & \multicolumn{1}{|c|}{ WFC } \\
\cline { 2 - 4 } & Pearson Correlation & & $-.572 * *$ \\
\cline { 2 - 4 } & Sig. (2-tailed) & & .000 \\
\cline { 2 - 4 } & N & 99 & 98 \\
\hline
\end{tabular}

**. Correlation is significant at the 0.01 level (2-tailed).

According to the results of the statistical test which exhibit in table 5.14, Pearson correlation coefficient between two variables is -0.572 . This shows that there is a substantial negative relationship between job satisfaction and work family conflict. This relationship is statistically significant as correlation is significant at 0.01 level (As Sig 0.000 which is lower than 0.01 ). Thus, it can be statistically claimed that there is a negative relationship between the two variables.

According to Table 4 and 5 regression equation of the job Satisfaction is:

Job Satisfaction $=4.842-0.630$ (work family conflict)

The $\mathrm{b}$ value of the equation, the gradient of the regression, is -0.630 which is significant at $1 \%$ (significant $=0.000$ ). As indicated by $\mathrm{R}$ Squared, $32.7 \%$ of the variance of job satisfaction is explained by work family conflict with the standardized beta of -0.572 . 
Table 4: Results of Regression Analysis

\begin{tabular}{|l|l|l|l|l|}
\hline Model & $\mathrm{R}$ & R Square & Adjusted R Square & $\begin{array}{l}\text { Std. Error of the } \\
\text { Estimate }\end{array}$ \\
\hline 1 & $.572^{\mathrm{a}}$ & .327 & .320 & .54602 \\
\hline
\end{tabular}

\section{Discussion and Conclusion}

It was found that there is a negative relationship between the work family conflict and job satisfaction of employees of the selected three banks. The correlation between these variables was -0.572 , which is significant at 0.000 levels. Discussing the level of work family conflict of the respondents in the sample, it was found that they have a high level of work family conflict with the mean value of 3.3056 and standard deviation of 0.597. Accordingly, it was found that the work family conflict level of private banks employees in selected three banks is high.

Table 05: Results of Regression Analysis

\begin{tabular}{|l|l|r|r|r|r|r|}
\hline \multicolumn{2}{|l|}{} & \multicolumn{2}{|l|}{$\begin{array}{l}\text { Unstandardized } \\
\text { Coefficients }\end{array}$} & \multicolumn{2}{l|}{$\begin{array}{l}\text { Standardized } \\
\text { Coefficients }\end{array}$} & \\
\cline { 3 - 6 } Model & B & Std. Error & Beta & T & Sig. \\
\hline 1 & (Constant) & 4.842 & .310 & & 15.608 & .000 \\
\cline { 2 - 7 } & WFCAvg & -.630 & .092 & -.572 & -6.830 & .000 \\
\hline
\end{tabular}

Some researchers discovered that there is no impact of work family conflict on job satisfaction. (Lyness \& Thomas 1997; Thompson \& Blau 1997). These arguments do not match with the findings of this study. According to the empirical data, a number of studies have examined the relationship between work-family conflict and job satisfaction and found that work-family conflict was negatively related to job satisfaction (Aryee 1993; Noor 2002; Aminah 1996). In addition, more research has explored the effects of work family conflict to the women's job satisfaction which reported that work-family conflict was negatively related to married women's job satisfaction (Aryee 1993, Bedeian \& Mossholder 1989). Beutell and Writing-Berman (1999) found that high levels of work family conflict are related to lower job satisfaction. The results of this study match with the findings.

The main objective of the study is to explore the impact of work family conflict on job satisfaction in private banks. Thus, researcher developed the hypothesis that there is a negative impact of work family conflict on job satisfaction. According to the empirical evidence, there is a negative relationship and impact between the work family conflict and job satisfaction of employees in selected banks. It indicates that work family conflict level of employees negatively contributes to the level of satisfaction.

The main findings of the study was that there is a negative impact of work family conflict on job satisfaction of employees in selected three banks. Also, the level of work family conflict of the employees is at a high level. Thus, some programs can be recommended to reduce the level of work family conflict of employees in the three banks. Job Design, Job Enlargement, 
Job Rotation, Opportunities for Promotion, Telecommunication and Flextime can be implemented to reduce work family conflict and to increase job satisfaction. However, there are some limitations in this study. Work family conflict is not the only factor which affect job satisfaction. This is one limitation of the research. Another important limitation is time constraint. Methodological limitation is another limitation. The dimensions and indicators of each variable were limited to primary data. The data, which were collected through a questionnaire and interviews may not be fully accurate due to many reasons such as, reluctance of the people to expose their real situations (they may concern secrecy) this may occur as a result of the organizational citizenship behavior. These findings and the conclusions of the research are based on the above limitations and the constraints.

\section{Reference}

i. Aminah, A 1996, 'Work-family conflict among married professional women in Malaysia', The Journal of Social Psychology, Vol.136, No.5, pp. 663-665.

ii. Arora, R, Stoner, CR \& Hartman, RL 1991, 'Work-family conflict: A study of women in management', Journal Applied Business Research, Vol. 7, pp. 67-73.

iii. Aryee, S 1993, 'Dual-earner couples in Singapore: an examination of work and nonwork sources of their experienced burnout', Human relations, Vol. 46, pp. 1441-1468.

iv. Bedelan, A \& Mossholder, K 1989, 'Work experiences: Job performance, and feeling of personal and family well-being', Journal of Vocational Behavior, Vol. 31, pp. 200275.

v. Beutell, N \& Wittig-Berman, U 1999, 'Predictors of work-family conflict and satisfaction with family, job, career, and life', Psychological Reports, Vol. 85, pp. 893-903.

vi. Carter, S \& Cannon, T 1992, Women as entrepreneurs, London, Academic Press.

vii. Frone, MR 2003, Work family balance, Handbook of occupational health psychology, pp. 143-162. Washington, DC, American Psychological Association.

viii. Kopelman, RE, Greenhaus, JH \& Connolly, TF 1983, 'A model of work, family, and interrole conflict: A construct validation study', Organizational Behavior and Human Performance, Vol. 32, pp. 198-215.

ix. Kossek, EE \& Ozeki, C 1998, 'Work-family conflict, policies, and the job-life satisfaction relationship: A review and directions for organizational behavior human resources research', Journal of Applied Psychology, Vol. 83, pp.139-149.

x. Kottawatta, H 2014, Research guide book, Department of Human Resource Management, Colombo.

xi. Lyness, KE \& Thompson, DE 1997, 'Above the glass ceiling? A comparison of matched samples of female and male executives', Journal of Applied Psychology, Vol. 82, No. 3, pp. 359-375.

xii. Maren, R, Pitarelli, F \& Cangiano, F 2013, 'Work-life balance and job satisfaction among teachers', Interdisciplinary Journal of Family Studies, Vol.18, pp.51-72.

xiii. Mohd, KMH 1993, 'Overall job satisfaction among managerial employees in the Public Services Department', Malaysia, Serdang. 
xiv. Nadeem, MA, Abbas \& Qaisar, 2009, 'The Impact of Work Life Conflict on Job Satisfactions of Employees in Pakistan', International Journal of Business and Management, Vol.4, No. 5.

xv. Netemeyer, RG, Boles, JS \& McMurrian, R 1996, 'Development and validation of work-family conflict and family-work conflict scales', Journal of Applied Psychology, Vol. 81, pp. 400-410.

xvi. Noor, NM 2002, 'Work-family conflict, locus of control, and women's well-being: Tests of alternative pathways', Journal of Social Psychology, Vol. 142, No. 5, pp. 645-662.

xvii. Parasuraman, S, Greenhaus, JR, Rabinowitz, S, Bedeian, AG \& Mossholder, KW 1989, 'Work and family variables as mediators of the relationship between wives' employment and husbands' well-being', Academy of Management Journal, Vol. 32, pp. 185-201.

xviii. Sekaran, U 1999, 'Understanding the Dynamics of Self Concept of Members in DualCareer Families', Journal of Human Relations, Vol. 42, pp. 97-116.

xix. Stephens, GK \& Sommer, SM 1996, 'The measurement of work to family conflict', Educational and Psychological Measurement, Vol. 56, No. 3, pp.475-486.

xx. Thompson, CA \& Blau, G 1993, 'Moving beyond traditional predictors of job involvement: Exploring the impact of work-family conflict and ever load', Journal Social Behaviour, Vol. 8, pp. 635-646.

Weerasinghe, KPNN

HR Executive, Ideal Motors (Pvt) Ltd. nayomiweerasingh27@gmail.com

\section{Batagoda, CK}

Senior Lecturer, Department of Human Resource Management, University of Sri Jayewardenepura kusumalib@gmail.com 